\title{
Article Structures: Moving from Printed to e-Dictionaries*
}

\author{
Rufus H. Gouws, Department of Afrikaans and Dutch, Stellenbosch \\ University, Stellenbosch, South Africa (rhg@sun.ac.za)
}

\begin{abstract}
By means of an overview of certain aspects of article structures in printed dictionaries and with reference to some examples from e-dictionaries a number of features of article structures in e-dictionaries are discussed. Reference is made to the positioning of articles in article stretches and functional partial article stretches. Different structural components of articles, i.e. text segments, comments and search zones are distinguished. The increased role of data-identifying entries as a type of non-typographical structural indicator in e-dictionaries receives attention as well as the fact that the traditional division of an article in two comments, typically a comment on form and a comment on semantics, cannot merely be maintained. The value of the cohesion resulting from the use of comments in printed dictionaries is much more restricted in e-dictionaries. The use of search zones and rapid access to these zones have a much more important role in the article structure of edictionaries. In the planning of e-dictionaries provision needs to be made for a multi-layered article structure with screenshots that display the data in a variety of search zones. Access to these search zones goes via structural indicators in an opening or further screenshot. Provision needs to be made for one lemma to occur in a comprehensive article but also in a number of restricted articles that can be retrieved from the same database. Users should also have the opportunity to design their own user profile that will allow them to consult dictionary articles structured according to their specific needs.
\end{abstract}

Keywords: ARTICLE STRUCTURE, COMMENT, COMPREHENSIVE ARTICLE, DATAIDENTIFYING ENTRY, e-DICTIONARIES, ITEM, MULTI-LAYERED ARTICLES, NON-TYPOGRAPHICAL STRUCTURAL INDICATOR, PARTIAL ARTICLE STRETCH, RESTRICTED ARTICLES, SCREENSHOT, SEARCH ZONE, TEXT SEGMENTS, USER PROFILE

Opsomming: Artikelstrukture: vanaf gedrukte na e-woordeboeke. Aan die hand van ' $n$ oorsig oor bepaalde aspekte van artikelstrukture in gedrukte woordeboeke en met verwysing na 'n aantal voorbeelde uit e-woordeboeke word sekere kenmerke van artikelstrukture in e-woordeboeke bespreek. Daar word gekyk na die plasing van artikels in artikeltrajekte asook in funksionele artikeldeeltrajekte. Verskillende struktuurkomponente van artikels, te wete tekssegmente, kommentare en soeksones word onderskei. Die groter rol van data-identifiserende inskrywings as tipe nietipografiese struktuurmerker in e-woordeboeke kry aandag asook die feit dat die tradisionele verdeling in twee kommentare, tipies 'n vormkommentaar en 'n semantiese kommentaar, nie

* This article was the basis of a shortened version presented as a paper at the Nineteenth Annual International Conference of the African Association for Lexicography (AFRILEX), which was hosted by the Research Unit for Language and Literature in the SA Context, North-West University, Potchefstroom Campus, Potchefstroom, South Africa, 1-3 July 2014. 
sonder meer gehandhaaf word nie. Die waarde van die samehang wat kommentare in gedrukte woordeboeke meebring, is veel beperkter in e-woordeboeke. Die gebruik van soeksones en die kitstoegang daartoe speel 'n veel belangriker rol in die artikelstruktuur van e-woordeboeke. Vir ewoordeboeke moet 'n veelvlakkige artikelstruktuur met skermskote wat die data in 'n verskeidenheid soeksones vertoon, beplan word. Toegang tot soeksones geskied via struktuurmerkers in 'n openings- of verdere skermskoot. Daar moet daarvoor voorsiening gemaak word dat een lemma in 'n omvattende artikel maar ook in ' $n$ verskeidenheid beperkte artikels kan optree wat aan dieselfde databasis onttrek word. Gebruikers moet ook die kans kry om met behulp van die opstel van 'n eie gebruikersprofiel artikels te kan raadpleeg wat in terme van hulle eie behoeftes gestruktureer is.

Sleutelwoorde: AANDUIDER, ARTIKELDEELTRAJEK, ARTIKELSTRUKTUUR, BEPERKTE ARTIKELS, DATA-IDENTIFISERENDE INSKRYWING, e-WOORDEBOEKE, GEBRUIKERSPROFIEL, KOMMENTAAR, NIETIPOGRAFIESE STRUKTUURMERKER, OMVATTENDE ARTIKELS, SKERMSKOOT, SOEKSONE, TEKSSEGMENTE, VEELVLAKKIGE ARTIKELS

\section{Introduction}

Within the field of theoretical lexicography research of the past decades has focused on various topics, including the contents of dictionaries, dictionary structures and lexicographic functions. Theoretical lexicography only emerged long after the lexicographic practice had been firmly established. In many of the developments in theoretical lexicography metalexicographers too often only looked backwards and in their theoretical approaches discussed the contents and structures of dictionaries of the past. Too seldom did they utilise their position to develop models for dictionaries of the future. This assignment was left in the hands of practical lexicographers. To ensure successful lexicographic endeavours, both in terms of theoretical developments and practical dictionaries, it is of paramount importance to maintain a strong and interactive relation between theoretical and practical lexicographers. Neither theoretical nor practical lexicographers should work isolated from the other party. The most important assignment of metalexicographers is not merely to devise models they deem appropriate for the lexicographic practice but rather to consult with practical lexicographers and only then to make suggestions that could enhance the lexicographic practice. As experts working in the field of an independent discipline metalexicographers should use their contact with the lexicographic practice to be innovative and to do research that can result in bringing new dictionary models and designs to the fore that can lead the way to new lexicographic dispensations.

The emergence of e-lexicography has presented metalexicographers with such an opportunity. Prevailing models, proposals and discussions in lexicographic theory were primarily directed at printed dictionaries. The golden opportunity to lead the way in devising models for e-dictionaries was unfortunately not utilised sufficiently by metalexicographers. Yet again too many lexicographic e-products were developed without any influence from innovative 
theoretical suggestions. Where practical lexicographers did utilise lexicographic theory it often was a version that had been devised for printed dictionaries. As a result current e-dictionaries too often do not live up to the expectations of their users. A better theoretical basis is needed and that should result in better e-dictionaries.

It is necessary to devise theoretical models for e-dictionaries that focus on critical areas like the data to be included in these dictionaries, the structures to present and accommodate the data, the functions of these dictionaries and the way they should respond to the needs of their target users. Dictionary structures, one of the prominent features of a general theory of lexicography, need to be re-investigated in order to determine which structures are needed in edictionaries. The importance of dictionary structures for the successful distribution and presentation of data should never be underestimated. This does not only apply to printed dictionaries but also to e-dictionaries. One of the noticeable features of too many e-dictionaries is a lack of well-planned structures. As a result these dictionaries do not allow their users an optimal access to the data or a comprehensive retrieval of information from the data on offer. Metalexicographers need to pay much more attention to an adaptation of lexicographic theory for application to e-dictionaries. One such aspect that needs attention is the formulation and application of dictionary structures in e-dictionaries. Some structures found in printed dictionaries should be retained, some should be changed, and some should not be used in e-dictionaries, whereas some new structures may have to be introduced.

This paper investigates one structure that plays a significant role in printed dictionaries and is also relevant for e-dictionaries, i.e. the article structure. Lexicographic theory lacks a satisfactory formulation and explanation of this structure in e-dictionaries. A brief overview is given of article structures in printed dictionaries. Then some data from existing e-dictionaries are analysed and discussed. In the discussion suggestions are made for the planning of article structures in e-dictionaries.

\section{Article structures in printed dictionaries}

\subsection{Terminological clarity}

In the development of lexicographic theory the German metalexicographer Herbert Ernst Wiegand played a dominant role in research regarding dictionary structures. In numerous publications, cf. Wiegand (1984, 1989, 1989a, 1989b, 1996, 2005), he introduced, identified and discussed a variety of dictionary structures in a meticulous way. Article structures also came to the fore in his publications, cf. Wiegand $(2002,2003)$ as well as Wiegand, Feinauer and Gouws (2013). The latter contribution forms a basis for the discussion in this paper.

Before discussing article structures, the term article or its longer form dictionary article has to be understood in an unambiguous way. The term dictionary 
article has not been used in all lexicographic environments. Quite often, especially in British lexicography, lexicographers have opted for the term dictionary entry. This paper uses dictionary article as the preferred term because there is an alternative use of the term dictionary entry, i.e. as referring to individual parts of dictionary articles and other texts in dictionaries. The default article, albeit not all articles, consists of at least a lemma sign. This lemma sign is the guiding element of the article and is usually followed by further entries presented as part of the treatment of the lemma. According to Wiegand, Feinauer and Gouws (2013: 317) a dictionary article is an accessible dictionary unit and it is characterised by three definitive features, i.e. "(a) It shows at least one external access text element. (b) It is a constituent of a wordlist. (c) It consists of lexicographic data made accessible, including at least one such part, by means of which the dictionary user can unlock lexicographic information mentioned by the access text element."

Accessibility is a critical feature of article structures. In printed dictionaries external data accessibility is established by the outer access structures, cf. Wiegand, Feinauer and Gouws (2013: 325). Another important feature of dictionary articles in printed dictionaries is the fact that they are part of a word list, typically the list containing all the macrostructural elements. This has immediate implications for their possible occurrence in e-dictionaries where word lists are not always an obvious structural component.

\subsection{The environment of dictionary articles}

In the majority of dictionary types lexicographers employ the macrostructure as an ordering structure to present lemmata as guiding elements of their respective dictionary articles. In a printed dictionary adhering to an alphabetical ordering the main macrostructure will consist of a series of article stretches. In alphabetically ordered dictionaries article stretches typically coincide with the 26 letters of the alphabet. However, this is not always necessarily the case. Some languages do not use specific letters whilst other languages have additional letters. A lexicographer of a dictionary dealing with Northern Sotho could e.g. consider including a separate article stretch for the letter "Š", seeing that this letter has a frequent occurrence in this language. Some Afrikaans dictionaries, e.g. Nasionale woordeboek, does not have an article stretch "Q" because, based on the needs of the target users of that dictionary, the lemma selection has not yielded any words starting with the letter "q".

According to Wiegand, Beer and Gouws (2013: 43) article stretches are immediate text constituents of the word list of an initial-alphabetical dictionary. As is the case with macrostructures, article structures can also be divided into those with a straight alphabetical ordering and those presented in a horizontal order as niched or nested article stretches. Any subsection of an article stretch, e.g. a given nest or niche, forms a partial article stretch and each partial article stretch is an immediate constituent of a specific article stretch. Wiegand, 
Beer and Gouws (2013: 48) make provision for functional partial article stretches, i.e. those partial article stretches "that display a genuine function directed at the dictionary subject matter." Such a functional article stretch could be formed on e.g. morpho-semantic grounds, etymological grounds, semantic relationships, etc. In many monolingual dictionaries that employ a system of horizontal macrostructural ordering the niches or nests are based on their relation with the preceding vertically ordered lemma. Compare in this regard the following excerpt from Groot woordeboek/Major Dictionary, a bilingual dictionary with Afrikaans and English as treated language pair, where the article of the lemma sign dak is followed by an article niche (of which only a part is given here). This niche is not only a partial article stretch (presenting the articles in the alphabetical stretch dakbalk-daklose) but it also is a functional partial article stretch because it includes words with the same lexical item, i.e. dak-, as first component and groups them together. With regard to the genuine purpose of functional article stretches Wiegand, Feinauer and Gouws (2013: 328) say: "They further show a genuine purpose, namely to indicate relationships regarding content between the lemma signs treated in the dictionary articles;" This partial article stretch satisfies the genuine function of macrostructural coverage of a specific subsection of the lexicon of Afrikaans.

dak, (-ke), roof; hanging wall (in mines); op iem. se $\sim$ AFKLIM, give someone a dressing down; onder $\sim$ BRING, give shelter; accommodate; ' $n \sim$ bo jou HOOF hê, have a roof over one's head; te veel op die HUIS hê, walls have ears; dit KRY ek op my , I shall have to answer for that; ONDER wees, have a roof over one's head; ONDER een $\sim$ sit, have common interests; SONDER $\sim$, roofless; van die $\sim$ ke af VERKONDIG, proclaim from the housetops; balk, roof beam; bedekking, roofing, roofage; $\sim$ bindbalk, principal beam; $\sim$ bint, roof-tie; $\sim$ boog, carline, hoopstick, roof (bow) stick; dekker, tiler; thatcher; drup, eaves, eaves-drip; fees, wetting the roof; fees vier, wet the roof; gesteente, roof wall; hanging rock; geut, eaves-gutter, eaves; cullis; hanger, roof pendant; roof hanger; $\sim$ hoog, as high as the roof; huis, penthouse; juk, ashlar; kamertjie, attic, garret; kap, roof-truss; roofpendant; principal; kiel valley; lamp, roof lamp; dome lamp; lat, roof lath; leer, cat ladder; lei, roof(ing) slate; lig, skylight; rooflight; loos, (..lose), roofless, homeless; lose, (-s), waif, homeless person;

\section{(Groot woordeboek/Major Dictionary)}

When looking at articles in e-dictionaries one also needs to look at their environment and at the article stretches to which they belong. This can have implications for the structure of these articles. An article in a niche or nest will often have a different structure compared to articles in a partial article stretch of vertically ordered lemmata. This issue will not be discussed in the present paper. 


\section{Types of articles}

Wiegand (2003) as well as Wiegand, Feinauer and Gouws (2013) argue in favour of a typology of articles. Wiegand, Feinauer and Gouws (2013: 318) distinguish different article formation features, e.g. condensation features, access structural features, macrostructural features, data distribution features, mediostructural features, microstructural features, text architectural features, quantity features, standardisation features, addressing features and search area structural features. These features lead to a typology system, consisting of a variety of typologies and within each one of these typologies a number of different types of articles can be identified.

Albeit that this paper will not repeat the discussion of this classification and the different types of articles identified in the discussion many aspects from that discussion are relevant when it comes to a determination of the structures of dictionary articles. Some of these features will play a role in the present discussion.

Different article types found in printed dictionaries also occur in e-dictionaries, e.g. partially condensed articles, single articles and synopsis articles, complex articles, etc. The use in printed dictionaries of a heterogeneous article structure, even in a single dictionary, is relevant to e-dictionaries. Consequently the notion of comprehensive and restricted articles for e-dictionaries will be introduced in this paper.

\section{Structural components of dictionary articles}

In terms of Wiegand and Beer $(2013: 255,256)$ three types of text constituent structures can be distinguished, i.e. article constituent structures and their partial structures, i.e. article microstructures and search area structures. From a slightly different perspective three different types of structural components of articles could be distinguished and will be discussed in the following sections, i.e. text segments, comments and search zones. These components form part of the structures of articles in printed dictionaries but they also play an important part in e-dictionaries. Lexicographers of e-dictionaries will do well to familiarise themselves with these components in order to plan their dictionaries in a much better way.

\subsection{Text segments}

Wiegand and Smit (2013: 152) regard a functional text segment as a

part of a condensed lexicographical accessive entry consisting of a form and at least one genuine function which is assigned to the form in its entirety.

The nature and functions of text segments need to be evaluated in order to determine their occurrence within the articles of e-dictionaries. Articles contain 
two types of text segments, i.e. items and indicators. Items are given as part of the microstructure whereas indicators do not belong to the microstructure but rather to the article structure. Items are data-carrying entries from which the user can retrieve information relevant to fulfilling the genuine purpose of the specific dictionary. These entries include e.g. items giving the pronunciation, morphology, part of speech, paraphrase of meaning, translation equivalents, illustrative examples, etc. Structural indicators are not data-carrying entries but they identify certain items or article slots. Wiegand (1989: 428) distinguishes between typographical, e.g. bold, italics, roman, etc., and non-typographical structural indicators, e.g. symbols like $*, \rightarrow$ and $\mathbf{m}$, or other markers used in the dictionary article, including semi-colons and commas or numbers marking the subcomments on semantics in the article of a lemma representing a polysemous lexical item. According to Wiegand and Smit (2013: 153):

A non-typographical microstructural indicator is a functional text segment without item function but with text constituent status within an article constituent structure which denotes microstructural text constituents.

The articles of any e-dictionary will necessarily contain items. The way in which they are presented will be discussed in subsequent paragraphs. The one significant difference between printed dictionaries and many e-dictionaries lies in the use and especially the nature of structural indicators. Items need to be identified and made accessible and this is the role of indicators in printed dictionaries. Some e-dictionaries maintain a more or less traditional use of both items and structural indicators as their text segments. However, although many e-dictionaries maintain some traditional structural indicators, others deviate in many ways from the approach prevalent in printed dictionaries. This constitutes a new feature of the article structure in e-dictionaries that needs to be investigated from a theoretical perspective.

Gouws (2014, in press) indicates that from the point of view of Information Science structural indicators in e-dictionaries are regarded as a part of the metadata because they guide the user to the required data. A type of entry that is also regarded as metadata in the field of Information Science are the entries giving an identification of the data because the user can retrieve information regarding the subject matter of the dictionary from them. They can be functionally segmented and are therefore also part of the rapid access structure. Dataidentifying entries, e.g. "COLLOCATION", "ANTONYM", etc. are structural indicators that give an explicit identification of the type of data accommodated in the relevant search zone. Varieties of this type of structural indicators often occur in e-dictionaries.

When designing e-dictionaries this use of indicators should be taken into account. Bothma and Gouws (2013) argue that when designing the article structure the lexicographer should decide on the levels of granularity and which fields need to be named for the sake of clarity. This is where data-identifying entries as a type of structural indicator can play an important role. It is necessary to draw a hierarchical tree structure of categories and sub-categories and 
to define relationships between categories. The database needs to be developed to reflect these decisions.

Within the article structure of printed dictionaries provision is also made for procedures of enrichment and expansion. Expansion implies that a given item can be up-, in- or downwardly extended in order to perform an additional treatment. Enrichment implies that a part of an item is typographically adapted, e.g. by means of caps, to distinguish it from other sections of the item and to put special focus on that item segment. Expansion leads to functional segmentation whereas functional segmentation is not possible in the case of enrichment. This aspect of the text segments of dictionary articles should also be discussed when looking at e-dictionaries.

Further reference to items and the use of indicators in e-dictionaries will be given in the section dealing with search zones.

\subsection{Comments}

According to Wiegand, Feinauer and Gouws (2013: 343) all immediate text constituents of a condensed dictionary article are called comments. Comments bring items together within the microstructure that belong together and by doing so they establish order and coherence in the article. A basic dictionary article consists of two comments, i.e. a comment on form and another comment, more often than not a comment on semantics. The following partial article from the Woordeboek van die Afrikaanse Taal (the WAT) has a comment on form and a comment on semantics. It shows an article-architecture with the data arranged in various text blocks - the comment on form in the first text block and the comment on semantics consisting of different subcomments on semantics in subsequent text blocks:

${ }^{1}$ maag s.nw., mae of soms mage en selde, veral in streek- of geselstaal, maagte; magie.

1 Sakagtige spysverteringsorgaan i.d. buikholte b.d. mens, wat die wydste deel v.d. spysverteringskanaal vorm tussen die slukderm en die duodenum, waarin die pas afgeslukte kos versamel, die koolhidrate gedeeltelik verteer word en die vertering van proteïen begin; sin. buik (verhewe of verouderend), pens (plat), kossak (skertsend; ongewoon): 'n Leë, vol maag. 'n Sterk, gesonde, goeie maag. 'n Swak maag. Pyn, krampe op jou maag hê. Naar op jou maag voel. Medisyne op jou nugter maag drink. Met ' $n$ honger maag bed toe gaan. Moenie op 'n vol maag gaan swem nie. $\approx$ 'n Maag wat gesond is, verteer maklik gewone voedsel (O. Schild: Voedingsl., s.j., 94). Hy het verlang om sy maag te vul met die peule wat die varke eet (Luk. 15: $16,1953)$. Uitgeput ... en met honger mae bereik die famielie ná ' $n$ vermoeiende stap die wa (Huisg., 27 Sept. 1929, 17). My kinders (word) nie verwaarloos ... nie ... hulle eet hulle mage trommelvol (J. v. Bruggen: Sluis'21, 1957, 48). Ons, die 
2 Min of meer soortgelyke orgaan of enigeen van verskeie soortgelyke organe by diere; dikw. sin. met pens: Herkouende diere het ' $n$... saamgestelde maag ... Dit is saamgestel uit vier afdelings (C.S. Grobbelaar in Pop.-Wet. Leesb. VI, 1920, 7). Die voedsel (ondergaan) (by herkouers) eers 'n voorlopige gisting in die voormaag ... voordat dit die werklike maag of melkpens en dermkanaal bereik).

3 a i Uitwendige gedeelte v.d. buik (BUIK I 1) v.d. mens; sin. buik (verhewe of verouderend), pens (plat); ook, (minder verhewe) buik (BUIK I 1): Plat op jou maag lê. Oor sy maag vryf.

\section{(Woordeboek van die Afrikaanse Taal)}

The articles in printed dictionaries display different comments, combinations of comments and article-internal positioning of comments. This will not be discussed in the present paper. Within the articles of e-dictionaries a similar occurrence of comments as seen in the article from the WAT is often found, cf. the following partial article from the monolingual Van Dale dictionary (Figure 1) where an article-architecture also prevails and where the items dealing with the comment on form have been allocated the first text block and the subcomments on semantics, constituting the comment on semantics, are ordered in subsequent text blocks:

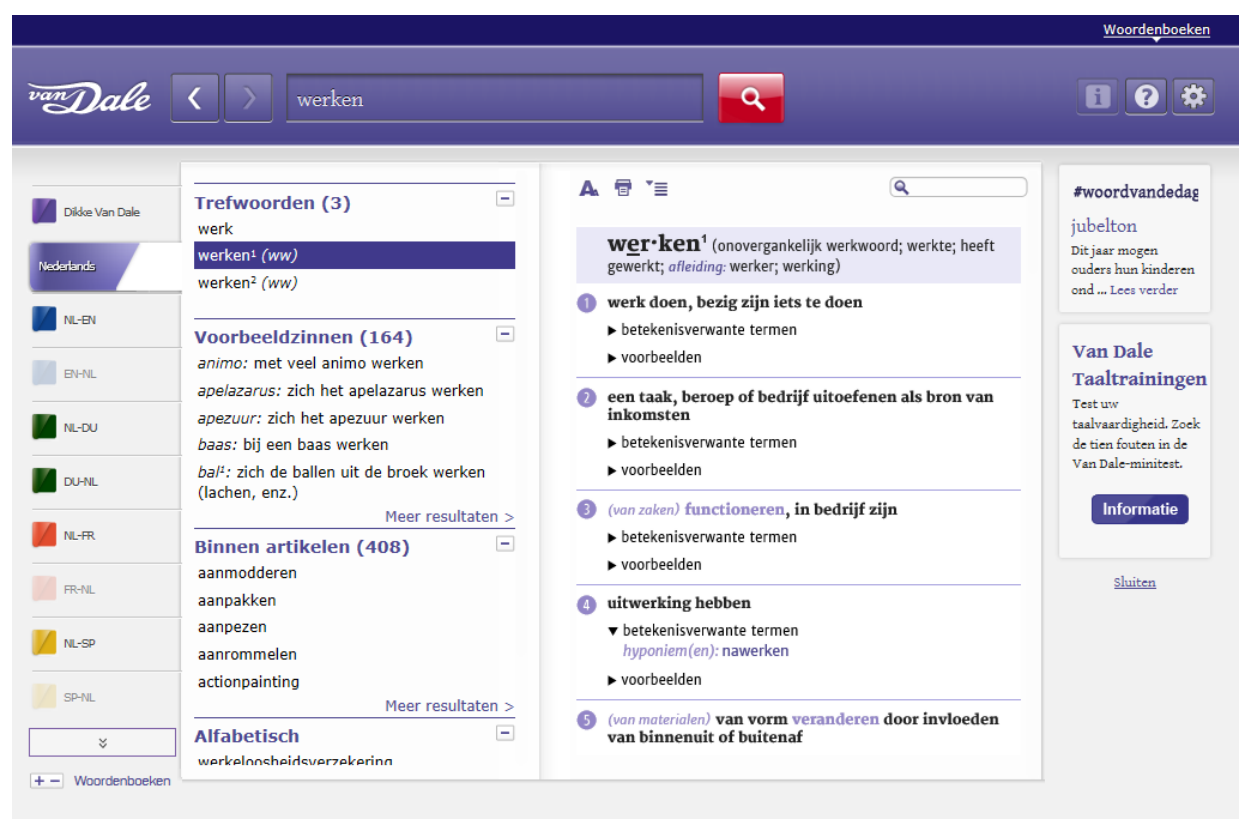

Figure 1 
The comments are venues to accommodate different types of lexicographic data. The data distribution in any dictionary needs to take the needs of the target users into account. This could result in a different ordering of data or even of comments, as e.g. seen in COBUILD with its innovative centre column, resulting in split comments with some of the typical items belonging to the comment on form given in the traditional position immediately after the lemma sign whilst others, e.g. grammar notes, are allocated a position in the centre column which also accommodates items like notes on semantic relationships from the comment on semantics. This centre column contains a hybrid comment, i.e. a comment on form and semantics.

Lexicographers of e-dictionaries have already employed strategies to deviate from a traditional ordering of comments in their dictionary articles. This is primarily the result of new data distribution options made possible by the e-environment. The dynamic nature of e-dictionaries enables lexicographers to move away from a static to a dynamic data display that includes the use of a multi-layered structure of dictionary articles. This is illustrated by the following screenshots from elexiko, one of the innovative online dictionaries of the Institute for German language in Mannheim, Germany. Figure 2 shows the result of a first search for the lemma Farbe where the user gets the option to go to the relevant article, cf. Figure 3. This first layer of the article structure, Figure 3, does not show a traditional presentation of a comment on form and a comment on semantics, but rather a rudimentary version of these comments that is divided into two text blocks not displaying the typical distribution of item types. One block contains data, including orthographic data that are usually allocated to the comment on form, but also a data-identifying entry that guides the user to data regarding word formation products. The data in this first text block are relevant to all the senses of the lemma. The second block contains sub-blocks for each of the senses. These sub-blocks contain a paraphrase of meaning and an option to proceed to another layer. Clicking on the structural indicator "weiter" (= further) in anyone of these sub-blocks guides the user to a further layer in the treatment of the lemma, cf. Figure 4. Here the paraphrase of meaning is repeated but the user can move to yet another layer of treatment by clicking on buttons, e.g. to find data on collocations or grammar. Clicking on the data-identifying entry "Grammar" guides a user to the display presented in Figure 5. The grammar data here would typically be part of a traditional comment on form but here it is isolated from the text block containing comment on form items seen in Figure 3.

The elexiko article of the lemma Farbe contains data comparable to what is found in printed dictionaries where a traditional division between the comment on form and the comment on semantics is maintained. However, a focus on options for rapid access to the specific data regarded as salient by a user in a specific situation of use eschews a structure comprised of a comment on form and a comment on semantics in favour of a multi-layered presentation with rapid access to a different grouping of items and data types that do not adhere to a typical comment on form and comment on semantics division. These excerpts from elexiko compel one to identify and acknowledge an important 
structure in e-dictionaries, i.e. the screenshot structure, and to realise that the static article structure in printed dictionaries is substituted by a dynamic multilayered article structure.

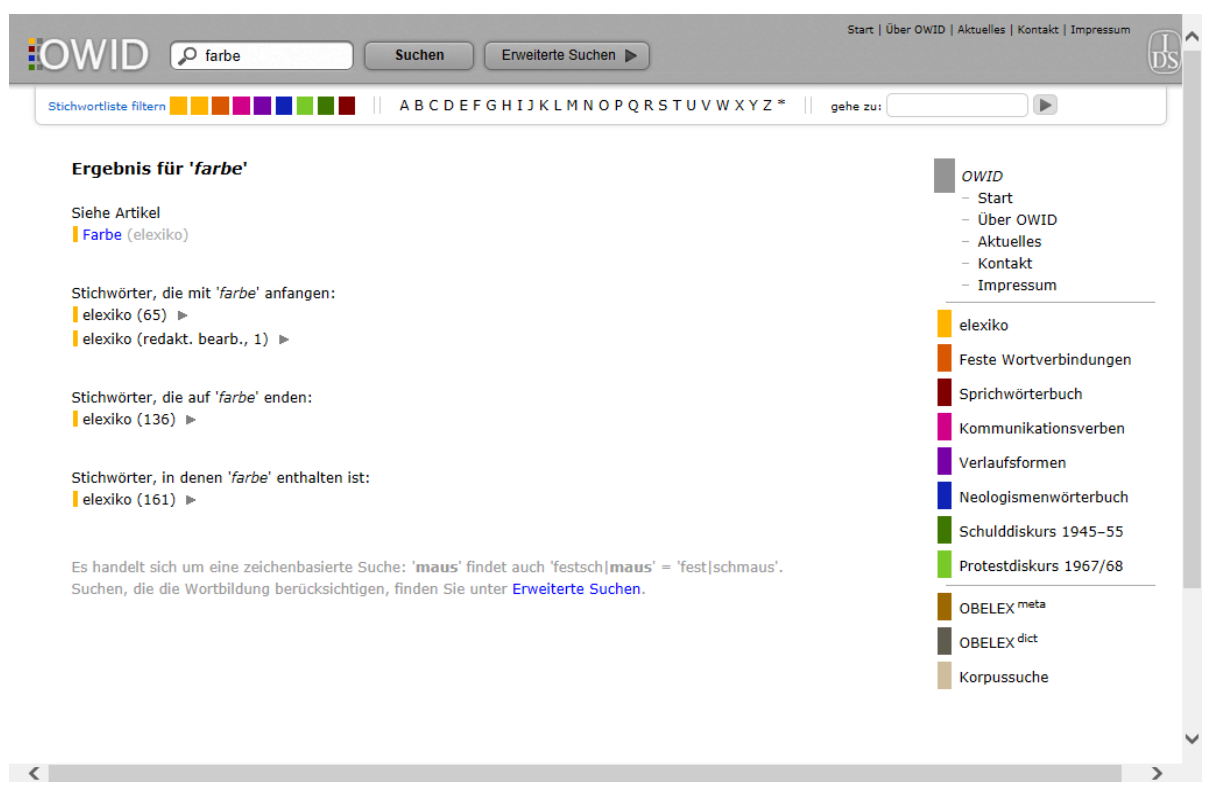

Figure 2

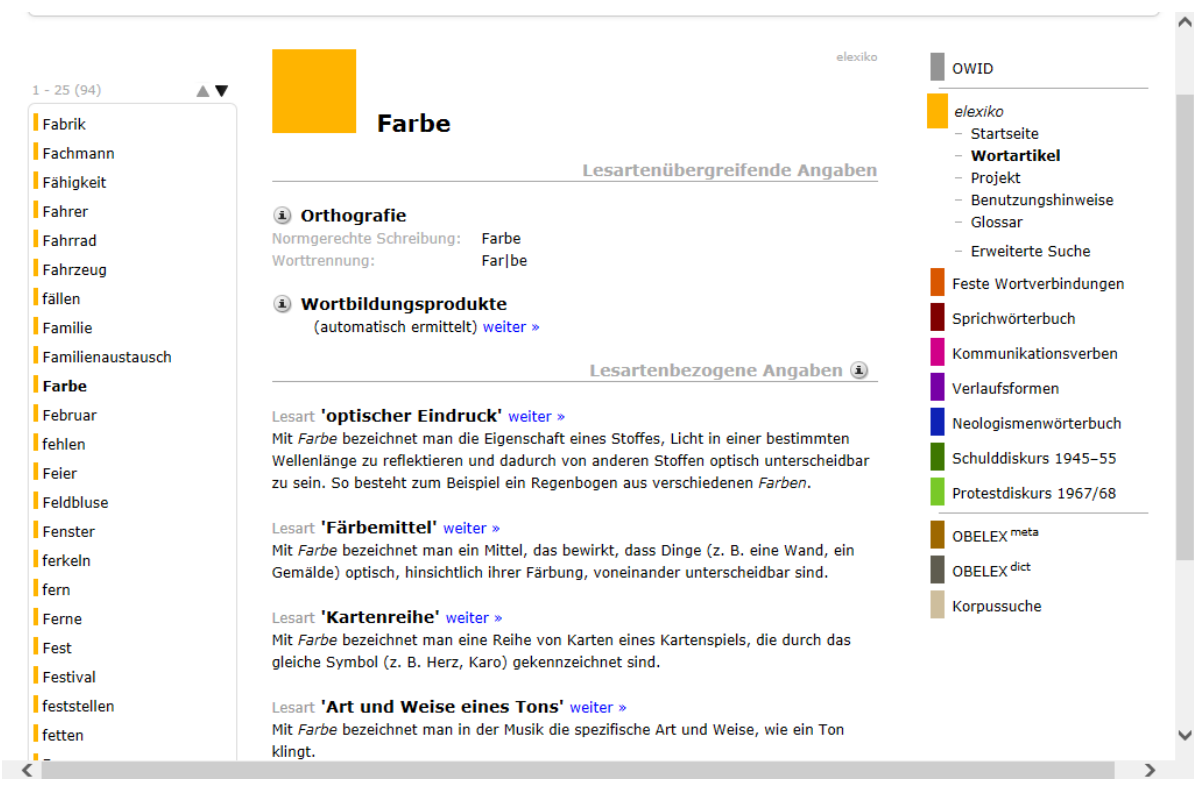

Figure 3 


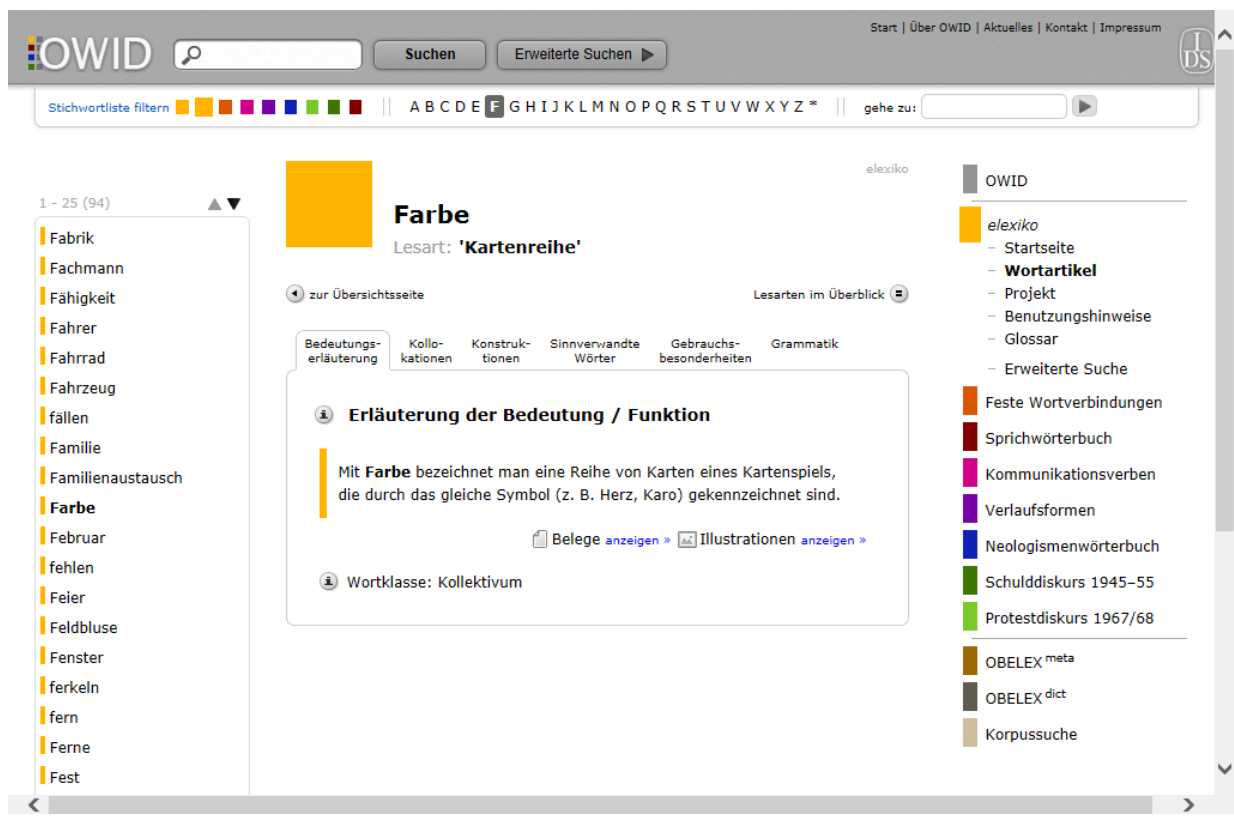

Figure 4

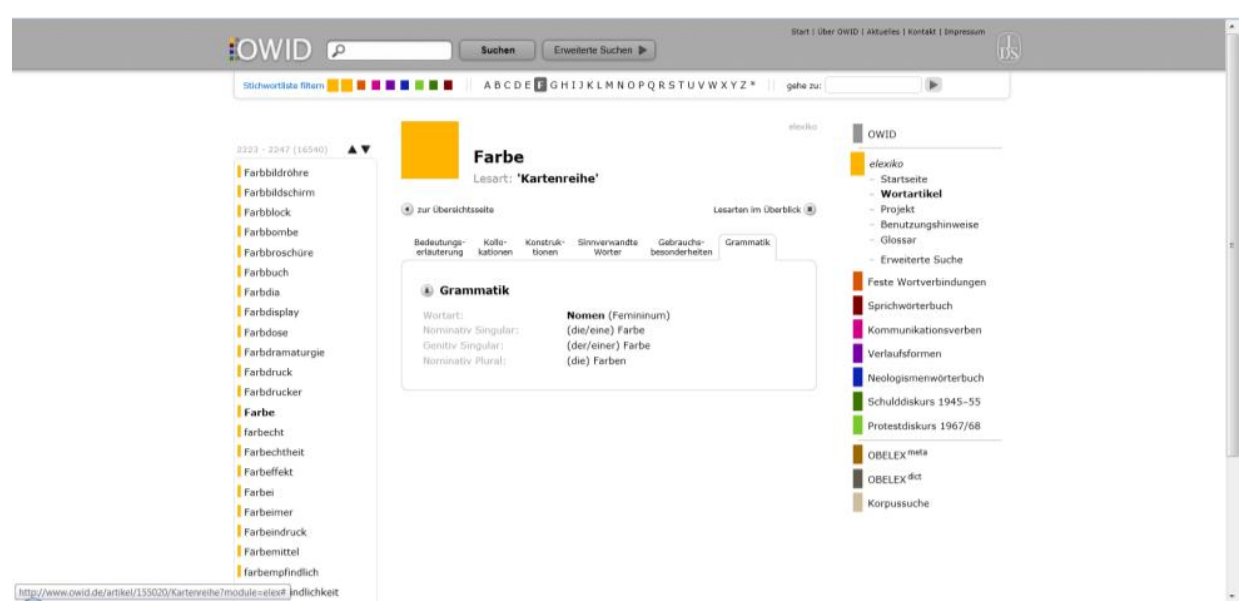

\section{Figure 5}

The screenshot structure is not exclusively part of an article structure - it is used in various other positions in e-dictionaries and can e.g. precede access to the article, e.g. as opening shot when consulting an e-dictionary for the first time. But it also plays a vital role in the structure of articles where the screenshot structure initiates access to the search zones, cf. 4.3 . 
Deviation from an absolute division between the comment on form and the comment on semantics is also seen in the German Duden Online. The following three screenshots, given here as three screenshots but actually representing a single display in the dictionary, show how the data in the article of the lemma Fenster have been ordered in different sections, each with a formal heading to indicate the data type, e.g. spelling, meaning, Did you know?, synonyms, pronunciation, origin, grammar, combinations. This article exhibits a definite article-architecture but the allocation of items to sections supersedes their allocation to comments. The topics that introduce each section help with explicit and rapid access to the relevant data so that the need for the cohesion provided by an ordering in two distinct comments becomes superfluous. This is also a multi-layered article structure. When clicking e.g. on a given paraphrase of meaning a screenshot opens with illustrative examples of all the different senses of the word Fenster, cf. Figure 9.

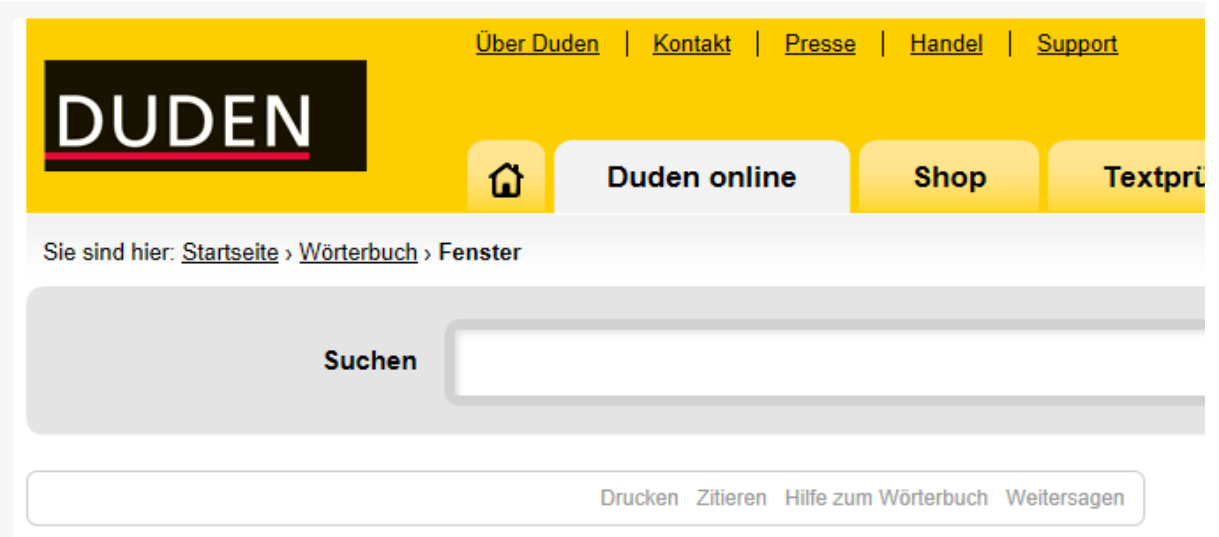

\section{Fenster, das}

Wortart: Substantiv, Neutrum

Häufigkeit:

Rechtschreibung (i

Worttrennung:

Fens|ter

\section{Figure 6}

The article structure in e-dictionaries can accommodate different comments but the new environment favours different procedures of grouping and access routes to data that do not lead via comments as article components. The allocation of lexicographic data to easily accessible search zones is of more importance than a strict adherence to a division in different comments. 
1.

a. meist verglaste Öffnung, die Licht [und Luft] in einen geschlossenen Raum dringen lässt

b. zum Verschließen der Fensteröffnung dienendes gerahmtes Glas

2. (umgangssprachlich) Kurzform für: Schaufenster

3. (EDV) auf dem Bildschirm eines Computers erscheinendes rechteckiges Feld, das dazu dient

Textteile, Teile eines Programmes oder andere Informationen zusătzlich auf der

Benutzeroberfläche darzustellen [und zu bearbeiten]

Wussten Sie schon?

Dieses Wort gehört zum Wortschatz des Zertifikats Deutsch.

Synonyme (i) zu Fenster

- Fensteröffnung

- Fensterglas, [Fenster]scheibe, Fensterverglasung, Glasfenster

- Auslage, Ladenfenster, Schaufenster

- (EDV) Window

Aussprache

Betonung:

Fẹnster 1(f))

\section{Figure 7}

Fẹnster (f))

\section{Herkunft (1)}

mittelhochdeutsch venster, althochdeutsch fenstar < lateinisch fenestra

\begin{tabular}{|l|l|l|}
\hline \multicolumn{2}{|l|}{ Grammatik (i) } & \multicolumn{2}{l|}{ Nach oben } \\
\hline Nominativ & Singular & Plural \\
\hline Genitiv & das Fenster & die Fenster \\
\hline Dativ & des Fensters & der Fenster \\
\hline Akkusativ & dem Fenster & den Fenstern \\
\hline
\end{tabular}

Typische Verbindungen (computergeneriert)

\begin{tabular}{l|l|l|}
\hline Adjektive & Verben & Substantive \\
\cline { 1 - 2 } & geheim & klein \\
offen & & geschlossen
\end{tabular}

Figure 8 


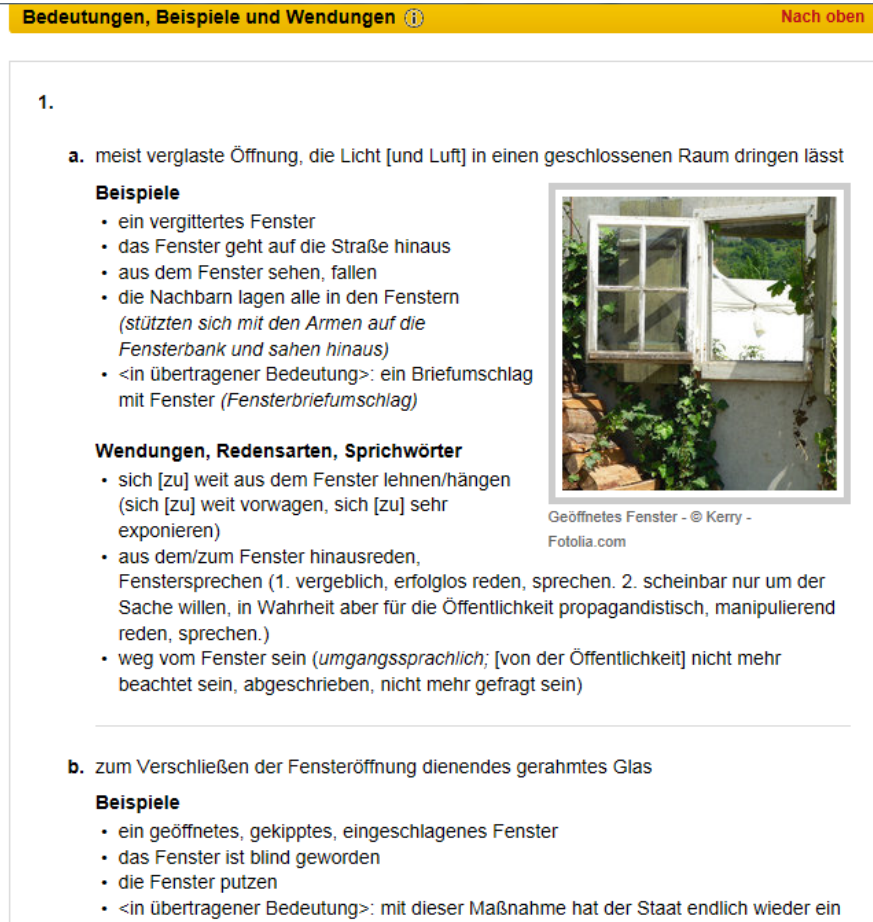

\section{Figure 9}

\subsection{Search zones}

Search zones constitute another category of structural components of articles in printed dictionaries. It also applies to e-dictionaries where adaptations can enhance the value of search zones to ensure a rapid and unambiguous retrieval of information. One of the advantages of a well-devised search zone structure is that it increases the user-friendliness of the dictionary considerably because of the clear demarcation of slots accommodating the different data types. The data distribution and presentation in e-dictionaries needs to be done in a meticulous way and in this regard the planning of clearly identifiable, findable and accessible search zones is of extreme importance. Search zones are subsections of dictionary articles and form part of a more comprehensive data distribution environment. The word list of a printed dictionary forms a search field, each dictionary article is a search area and all these search areas are divided into search zones, cf. Wiegand and Beer (2013). With regard to e-dictionaries it could be argued that the article stretch compound constitutes a search field with the articles and their subdivisions fulfilling a similar role as their counterparts in printed dictionaries. This is illustrated by the following partial article from the Oxford English Dictionary, the OED, Figure 10: 


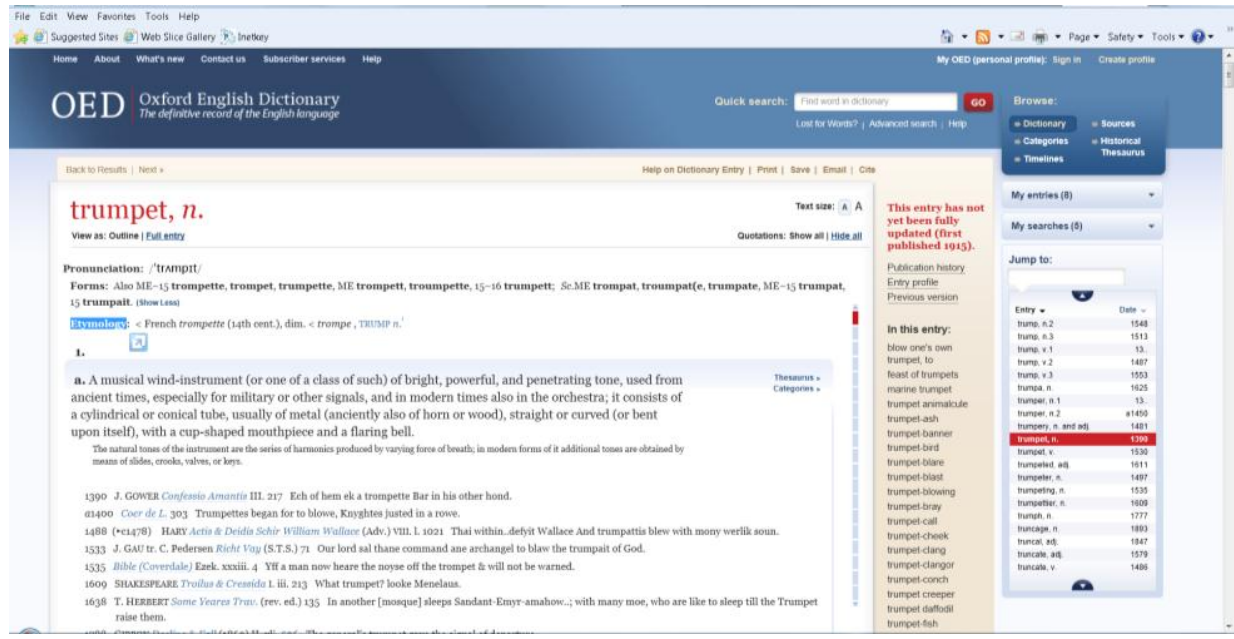

Figure 10

In this article different data types are clearly presented in different text blocks, i.e. search zones.

Wiegand, Beer and Gouws (2013: 64) argue that

Search zones have the general genuine function to assist the knowledgeable active dictionary user by means of search zone indicators in making the search for the items regarded as search targets easier.

They also stress the importance of a classification system of search zone indicators.

As is the case with comments, search zones could also have a similar display in printed and e-dictionaries, e.g. with regard to the use of typographical and non-typographical structural indicators, cf. Figure 11 from the WAT. Here one finds typographical indicators to present the lemma in bold, the paraphrases of meaning in roman and examples in italics and non-typographical indicators like numbers as polysemy markers and the black square "ø" marking specific types of additional data.

This similar use of especially non-typographical structural indicators as in printed dictionaries is often found in e-dictionaries that have a printed dictionary as its base. However, in dictionaries designed for the e-medium this use of non-typographical indicators is not needed because a multi-layered presentation of search zones typically employs data-identifying entries to guide the user to the relevant items or search zone. This can be seen in e.g. the data presentation and article structure of the previously discussed elexiko excerpts. As previously indicated in the discussion of elexiko the full article is not displayed at any one time. However, users can move from one layer to another by clicking on buttons that function as data-identifying entries as seen in Figure 4 from elexiko. 


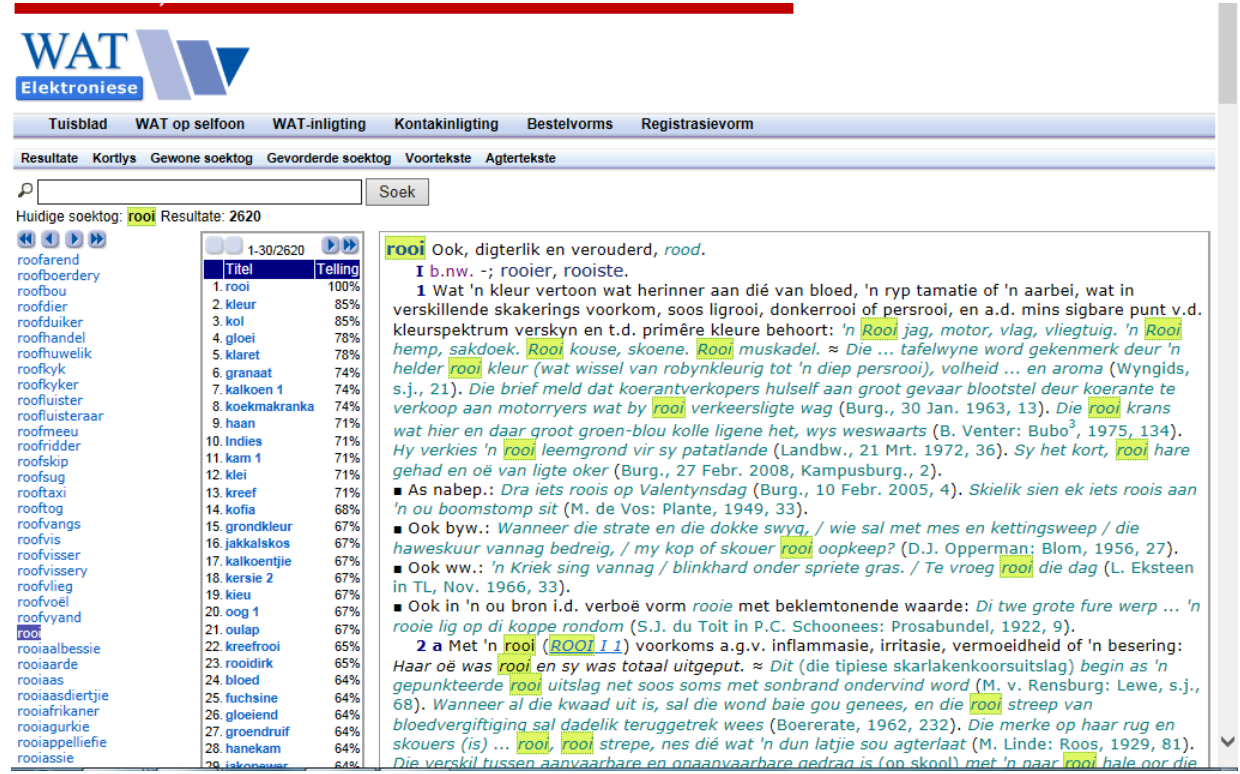

\section{Figure 11}

These data-identifying entries, e.g. "Kollokationen", "Konstruktionen" and "Grammatik", have the same function as structural indicators in printed dictionaries. They are the typical non-typographical structural indicators in e-dictionaries. Because they guide the user to the relevant search zone the use of other nontypographical indicators like symbols is not needed, cf. Bothma and Gouws (2013). These data-identifying entries are much more explicit, cf. Gouws (2014, in press), and users do not have to learn the value of a range of symbols that are used as non-typographical indicators.

In the articles of e-dictionaries the use of clearly-identified search zones is of extreme importance. Their occurrence in a multi-layered presentation within the article as search area could be regarded as one of the innovative aspects of e-dictionaries for which further research, also with regard to the use of dataidentifying entries as non-typographical structural indicators, can only enhance the lexicographic endeavour. In terms of Wiegand (2005) these non-typographical indicators need to help users with their article-internal orientation so that they are in a position to identify, distinguish and group different items.

\section{Different articles with the same guiding element}

It has already been shown that some e-dictionaries display an article structure that resembles that of the printed version of the dictionary, cf. Figure 12 from the American Heritage Dictionary: 


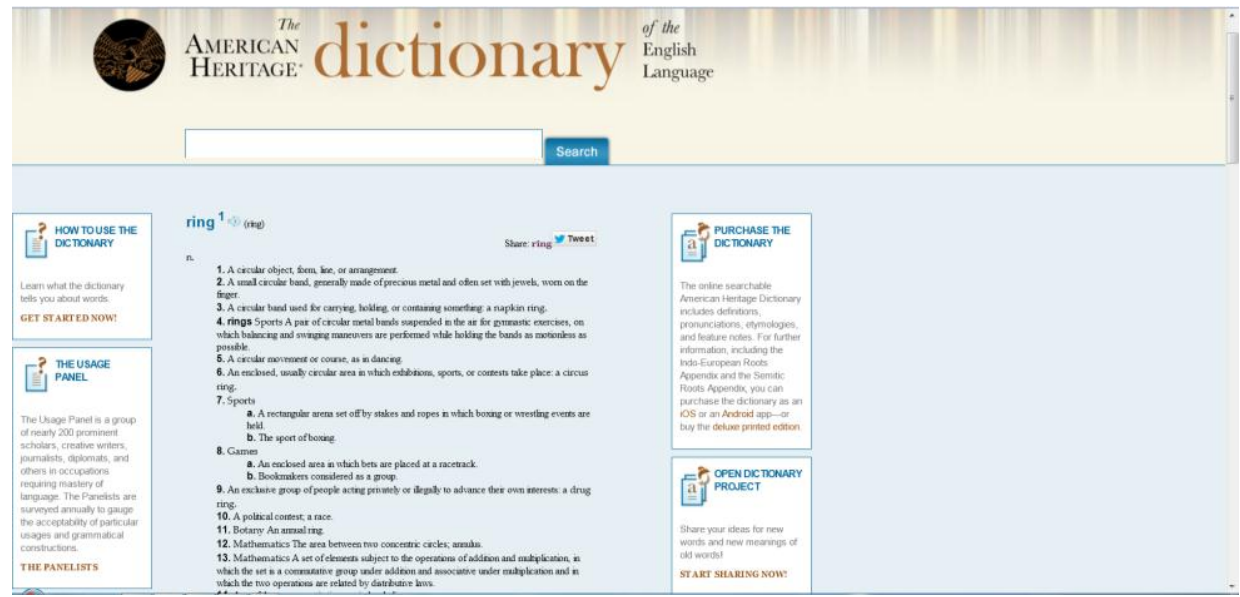

Figure 12

Lexicographers of e-dictionaries do have the option to structure articles in this way but in the planning of an online dictionary one needs to negotiate the spectrum of possibilities that the medium offers. One of the major advantages of online dictionaries is that users do not necessarily have to work through all search zones or items a dictionary offers in its default articles. Embarking on the e-possibilities some online dictionaries give access to the full article but, as seen in 4.3 , also allow the user to go directly to a specific search zone or the item giving the data he/she requires. This is done by means of rapid access using data-identifying entries that can either guide the user to a specific item or to a selected search zone. These procedures typically result in screenshots where the lemma is presented, complemented only by the desired data type, e.g. only an item giving the paraphrase of meaning, or only the translation equivalents or only whatever data type the user is looking for.

The entries displayed in such a presentation can also function as part of the comprehensive article structure of the given lemma but for the specific consultation such a lemma plus a single search zone or a single item function as fully-fledged articles. When consulting the Dutch Algemeen Nederlands Woordenboek the user may only be interested in the meaning of the word fado. Utilising the search options he/she may then reach the following destination, cf. Figure 13, i.e. a rudimentary dictionary article with fado as lemma, complemented by two abbreviated paraphrases of meaning to identify the different senses of this word. 


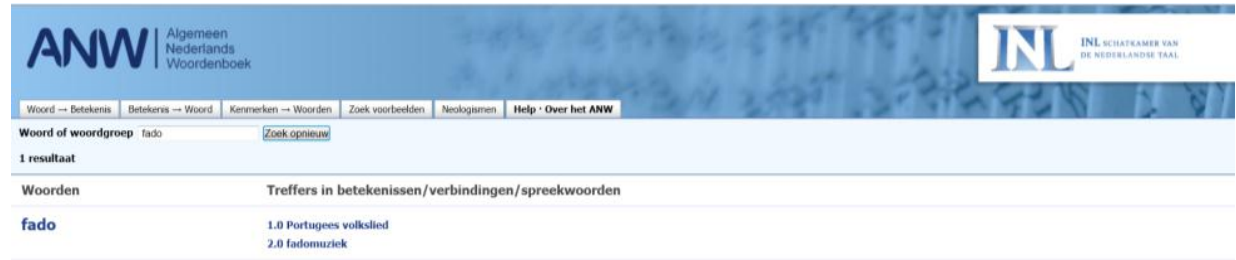

\section{Figure 13}

If the user is interested in the first polysemous sense he/she clicks on that sense, as data-identifying entry, and is guided to an article with a more comprehensive treatment directed at fado in that specific sense:

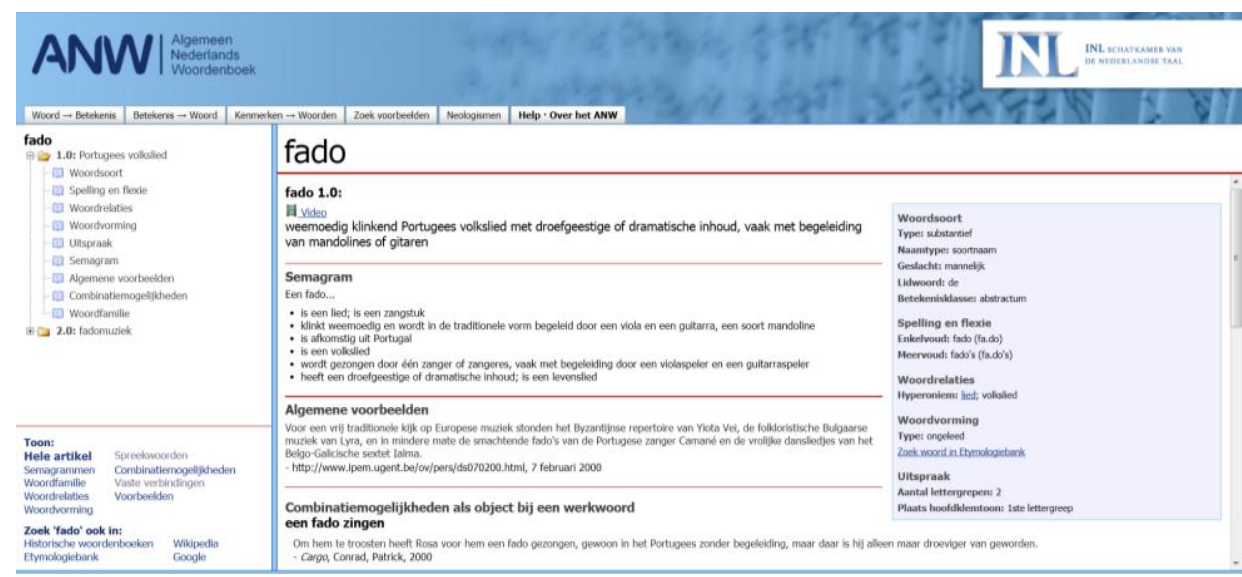

\section{Figure 14}

Interest in one data type, e.g. "word family" leads by means of a single click to the following article:

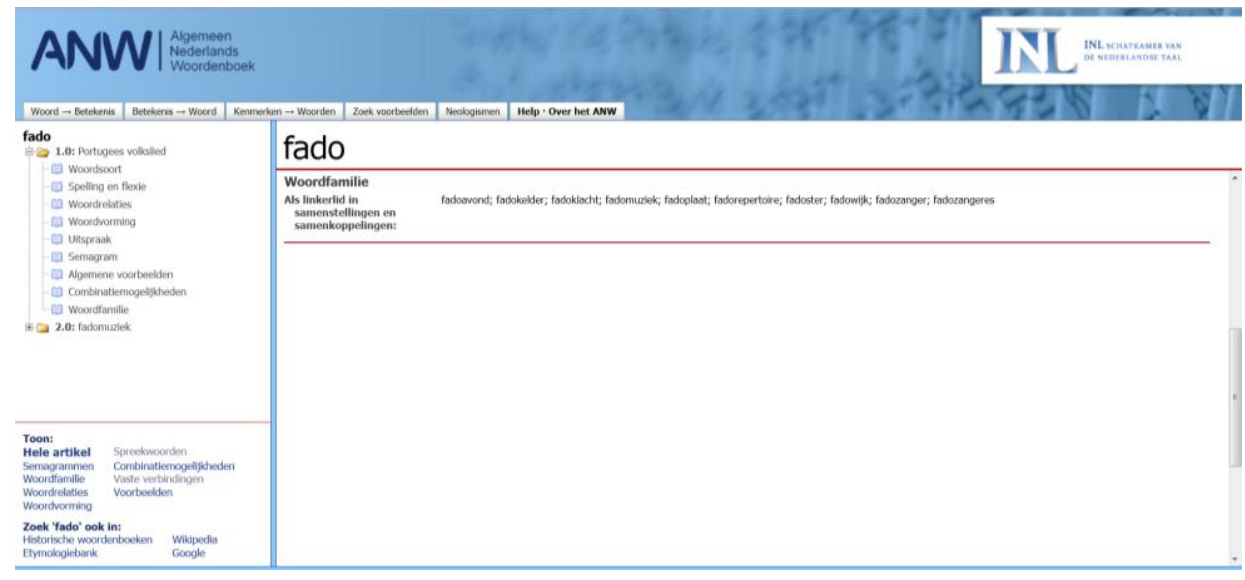

Figure 15 
A click on the entry Hele artikel (= full article) gives access to the full article. The article structure with its layered search zones and entries guiding the user to specific items meet the important criterion of external data-accessibility, as formulated by Wiegand, Feinauer and Gouws (2013: 325).

An access process that can direct searches to both comprehensive articles and articles with a restricted structure that are in complete accordance with the needs of the user elevates the value of a dictionary. When planning the treatment allocated to lemmata in e-dictionaries lexicographers should consider the possibility of layering search zones in such a way that the user can find various articles, each with its own unique article structure, for a single lemma where, once again, the function and the needs of the user determine the article structure, contents and presentation of data. The user should be able to extract different articles that have the same lemma from one single database and to access those articles and the specific data type by means of a search option determined by the specific need of the user in a specific situation of use.

Even within the domains of one function different articles with the same lemma should be possible. If the dictionary e.g. has a cognitive function the user should be able to access different data types included as part of the cognitive task identified for that dictionary. This implies that if the user is in need of etymological data a consultation should lead him/her directly to the etymological data and not to e.g. some encyclopaedic data in the paraphrase of meaning that have been included as part of the response to the cognitive function of the dictionary. Search zones are designed in terms of data types and not functions. However, for future dictionaries lexicographers could consider access to function-based search zones in the articles of bi- or polyfunctional dictionaries.

Different articles do not only have to be pre-planned in terms of their structure and the types of items to be included. These pre-planned articles, i.e. either comprehensive or restricted in format, can be seen as part of the default variation in structure. However, a further type of variation in article structure is needed in an online dictionary. The user should be given the opportunity to either use the default settings of the dictionary, i.e. e.g. the option to use the pre-planned and pre-set article structures as indicated above, or to create a user profile according to which any search will lead to the retrieval of information directly responding to the specific needs of the user in terms of the given profile. This implies that for a given user who has created his/her profile a nichemade article can be retrieved that is unique for that specific consultation procedure and the specific needs of the active user.

Within each dictionary easy and direct access to the individual data types or to the article as a whole should result from a choice the user can make at an early phase of the dictionary consultation process. The setting up of a user profile should also allow the establishment of the default article type for the specific user during a comparable consultation process. A prerequisite for these possibilities is a well-designed system of article structures that have been developed 
in accordance with the underlying theoretical basis of the dictionary.

Planning of a new online dictionary could also be done in such a way that not only different articles of the same lemma can be accessed but from a single database users should actually be able to access different dictionaries treating that lemma, cf. Bergenholtz and Nielsen (2013: 82). This implies a proper marking-up of database entries so that the retrieval of information is in line with the specific dictionary and the needs of the user in terms of his/her selected profile. The items needed for the different dictionaries need to be accommodated in a specific microstructure which is a component of the article structure. Different types of microstructures need to be considered for each dictionary in order to get the best structure for the ordering of the items in the specific articles. This should also be done with regard to the functions, users and situation of use of the specific dictionary.

\section{Conclusion}

The importance of lexicographic structures in e-dictionaries should not be underestimated but lexicographers may not follow an uncritical approach by merely trying to utilise the same structures as employed in printed dictionaries. The article structure needs to be maintained in e-dictionaries but with a different focus. As immediate constituents of article and partial article stretches, cf. Gouws (2014a, in press), or as immediate results of lexicographic search processes not going via an article stretch or an alphabet bar the division of an article into two or more comments should not be seen as a default structure. Data should rather be retrieved from different search zones constituting a multi-layered article structure with a variety of screen shots to present the relevant lexicographic data. Articles will always contain both items and structural indicators as text segments but the structural indicators in e-dictionaries will rather be of a non-typographic nature, utilising more data-identifying entries to ensure unambiguous and rapid access to the relevant search zones and items.

Access to specific search zones and data types with a required search zone being the only article component to complement the lemma sign leads to the acknowledgement of restricted articles. The data in these articles can also be presented in the comprehensive version of the article but its occurrence as only complement to the lemma qualifies the presentation as a fully-fledged article in its own right. This leads to heterogeneous article structures in a variety of restricted articles that share a single lemma. This lemma also functions as guiding element of a comprehensive article.

In the planning and compilation of e-dictionaries a varied article structure and the possibility to retrieve different articles with the same lemma from a single data base represent innovative features that do not prevail in printed dictionaries. The data distribution allocating items to hierarchically-ordered multi-layered search zones needs to be planned in accordance with the user needs and specific situations of use in order to enhance the success of the dic- 
tionary consultation process.

\section{Acknowledgement}

This research is (a) conducted within the SeLA project (Scientific e-Lexicography for Africa), supported by a grant from the German Ministry for Education and Research, administered by the DAAD and (b) supported in part by the National Research Foundation of South Africa (grant specific unique reference number (UID) 85434).

The Grantholder acknowledges that opinions, findings and conclusions or recommendations expressed in any publication generated by the NRF supported research are that of the author, and that the NRF accepts no liability whatsoever in this regard.

\section{Bibliography}

\subsection{Dictionaries}

\subsubsection{Printed dictionaries}

Botha, W.F. (Ed.-in-Chief). 1996. Woordeboek van die Afrikaanse Taal, Volume X. Stellenbosch: Bureau of the WAT.

De Villiers, Meyer et al. (Eds.). 19877. Nasionale Woordeboek. Cape Town: Nasou.

Eksteen, L.C. et al. (Eds.). 199714. Groot Woordeboek Afrikaans-Engels/Engels-Afrikaans / Major Dictionary Afrikaans-English/English-Afrikaans. Cape Town: Pharos.

Sinclair, J.M. (Ed.). 1987. Collins COBUILD English Language Dictionary. London/Glasgow: HarperCollins.

\subsubsection{Online dictionaries}

Algemeen Nederlands Woordenboek. http://anw.inl.nl/search

American Heritage Dictionary. http://ahdictionary.com/

Duden Online. http://www.duden.de/

elexiko. http://www.owid.de/wb/elexiko/start.html

Oxford English Dictionary. http://www.oed.com/

Van Dale woordenboeken. http://www.vandale.be/opzoeken

Woordeboek van die Afrikaanse Taal. http: //www.woordeboek.co.za.ez.sun.ac.za/

\subsection{Other literature}

Bergenholtz, H. and S. Nielsen. 2013. What is a Lexicographical Database? Lexikos 23: 77-87.

Bothma, T.J.D. and R.H. Gouws. 2013. Mapping Indicators in Print Dictionaries to Structural Descriptions in e-Dictionaries. Unpublished paper presented at the 2013 eLex Conference, 17-19 October 2013, Talinn. 
Gouws, R.H. 2014. In press. Aspekte des lexikographischen Prozesses in Print- und Onlinewörterbüchern. OPAL — Online publizierte Arbeiten zur Linguistik. Mannheim: Institut für Deutsche Sprache.

Gouws, R.H. 2014a. In press. Makrostruktuuraanpassings vanaf gedrukte na e-woordeboeke.

Gouws, Rufus H., Ulrich Heid, Wolfgang Schweickard and Herbert Ernst Wiegand (Eds.). 2013. Dictionaries. An International Encyclopedia of Lexicography. Supplementary Volume: Recent Developments with Focus on Electronic and Computational Lexicography. Berlin/ New York: Walter de Gruyter.

Hausmann, F.J. et al. (Eds.). 1989-1991. Wörterbücher. Dictionaries. Dictionnaires. An International Encyclopedia of Lexicography. Berlin: Walter de Gruyter.

Wiegand, H.E. 1984. On the Structure and Contents of a General Theory of Lexicography. Hartmann, R.R.K. (Ed.). 1984. LEXeter '83 Proceedings. Papers from the International Conference on Lexicography at Exeter, 9-12 September 1983: 13-30. Lexicographica. Series Maior 1. Tübingen: Max Niemeyer.

Wiegand, H.E. 1989. Der Begriff der Mikrostruktur: Geschichte, Probleme, Perspektiven. Hausmann, F.J. et al. (Eds.). 1989-1991: 409-462.

Wiegand, H.E. 1989a. Aspekte der Makrostruktur im allgemeinen einsprachigen Wörterbuch: Alphabetische Anordnungsformen und ihre Probleme. Hausmann, F.J. et al. (Eds.). 19891991: 371-409.

Wiegand, H.E. 1989b. Arten von Mikrostrukturen im allgemeinen einsprachigen Wörterbuch. Hausmann, F.J. et al. (Eds.). 1989-1991: 462-501.

Wiegand, H.E. 1996. Das Konzept der semiintegrierten Mikrostrukturen. Ein Beitrag zur Theorie zweisprachiger Printwörterbücher. Wiegand, H.E. (Ed.). 1996. Wörterbücher in der Diskussion II. Vorträge aus dem Heidelberger lexikographischen Kolloquium: 1-82. Lexicographica. Series Maior 70. Tübingen: Max Niemeyer

Wiegand, H.E. 2002. Über textuelle Strukturen der Wörterbuchartikel und Artikelnischen im de Gruyter Wörterbuch Deutsch als Fremdsprache. Zugleich ein Betrag zur Weiterentwicklung einer Theorie der Wörterbuchform. Wiegand, H.E. (Ed.). 2002. Perspektiven der pädagogischen Lexikographie des Deutschen II. Untersuchungen anhand des de Gruyter Wörterbuchs Deutsch als Fremdsprache: 497-595. Lexicographica. Series Maior 110. Tübingen: Max Niemeyer.

Wiegand, H.E. 2003. Überlegungen zur Typologie von Wörterbuchartikeln in Printwörterbüchern. Ein Betrag zur Theorie der Wörterbuchform. Lexicographica 19: 169-313.

Wiegand, H.E. 2005. Angaben, funktionale Angabezusätze, Angabetexte, Angabestrukturen, Strukturanzeiger, Kommentare und mehr. Ein Betrag zur Theorie der Wörterbuchform. Lexicographica. International Annual for Lexicography 21: 202-379.

Wiegand, H.E. and S. Beer. 2013. Access Structures in Printed Dictionaries. Gouws, Rufus H., Ulrich Heid, Wolfgang Schweickard and Herbert Ernst Wiegand (Eds.). 2013: 110-149.

Wiegand, H.E., S. Beer and R.H. Gouws. 2013. Textual Structures in Printed Dictionaries: An Overview. Gouws, Rufus H., Ulrich Heid, Wolfgang Schweickard and Herbert Ernst Wiegand (Eds.). 2013: 31-73.

Wiegand, H.E., I. Feinauer and R.H. Gouws. 2013. Types of Dictionary Articles in Printed Dictionaries. Gouws, Rufus H., Ulrich Heid, Wolfgang Schweickard and Herbert Ernst Wiegand (Eds.). 2013: 314-366.

Wiegand, H.E. and M. Smit. 2013. Microstructures in Printed Dictionaries. Gouws, Rufus H., Ulrich Heid, Wolfgang Schweickard and Herbert Ernst Wiegand (Eds.). 2013: 149-214. 